\title{
Development of great cormorant population (Phalacrocorax carbo sinensis) in North-East France - synthesis of long term monitoring (1997-2008)
}

\author{
M. Collas ${ }^{(1)}$, V. Burgun ${ }^{(1)}$ \\ Received December 17, 2010 \\ Revised June 27, 2011 \\ Accepted July 4, 2011
}

\section{ABSTRACT}

Key-words:

Alsace region, Lorraine region, ChampagneArdenne region, count, wintering population, nesting population, regulation
Since 1997, the North-east inter-regional delegation of the French National Institute for Water and Aquatic Ecosystems (ONEMA) has been running annual networked monitoring of the great cormorant (Phalacrocorax carbo sinensis) population in three French administrative regions: Alsace, Lorraine and Champagne-Ardenne. Changes in the wintering population are assessed by means of four monthly counts. Over the period 1997/2001, the population increased at a steady rate (average annual increase of 16\%). Taking the population in January as the reference, the year 2001 shows a peak population of 13000 birds. Since 2002, gradual decreasing in numbers has taken place (average rate of $-4.5 \%$ ). In January 2008 , less than 10000 birds were recorded. At the same time, nesting of the great cormorant was observed for the first time in Lorraine region in 1986. Then, the bird has been nesting in Champagne-Ardenne region and, since 2003 , in all three regions. In 2008, ten nesting colonies were identified, composed of 512 couples (annual increase in population of $30.2 \%$ ) and 1500 births were recorded in Spring. Parallel to nesting, 4605 great cormorants were killed during the winter of 2007/2008 for a population of 10000 birds. Climatic conditions may cause significant changes in wintering movements of the species, while operations to regulate cormorant numbers do not seem to have significant impact on the level of frequentation in winter. Finally, the using conditions of certain artificial lakes seem to be favourable for the bird during particularly difficult periods.

\section{RÉSUMÉ}

Évolution récente des populations du grand cormoran (Phalacrocorax carbo sinensis) dans le nord-est de la France - Synthèse de onze années de suivi (1997-2008)

Mots-clés :

Alsace, Lorraine, ChampagneArdenne, comptage
Depuis 1997, la Délégation interrégionale du nord-est de l'Office National de l'Eau et des Milieux Aquatiques (ONEMA) a mis en place un réseau de suivi annuel de la population du grand cormoran (Phalacrocorax carbo sinensis) dans les régions Alsace, Lorraine et Champagne-Ardenne. L'évolution de la population hivernante est appréciée chaque hiver au travers de quatre comptages mensuels. Durant la période 1997/2001, la population interrégionale a progressé régulièrement (taux de croissance moyen annuel de $16 \%$ ). En prenant comme référence la population

(1) Office National de l'Eau et des Milieux Aquatiques (ONEMA), Délégation interrégionale du nord-est,

23 rue des Garennes, 57155 Marly, France, marc.collas@onema.fr; vincent.burgun@onema.fr 
population hivernante, population nicheuse, régulation du mois de janvier, cette population culmine à plus de 13000 oiseaux en janvier 2001. Depuis 2002, une érosion des effectifs est observée (taux moyen de $-4,5 \%$ par an) avec moins de 10000 oiseaux recensés en janvier 2008. Parallèlement, la nidification du grand cormoran est observée pour la première fois en Lorraine en 1986. L'oiseau niche ensuite en Champagne-Ardenne et, depuis 2003, dans les trois régions. En 2008, on dénombre dix colonies nicheuses pour un total de 512 couples (taux de croissance moyen annuel de 30,2 \%) et 1500 naissances enregistrées. Dans le même temps, 4605 grands cormorans étaient abattus au cours de l'hiver 2007/2008, pour une population recensée de près de 10000 oiseaux. Les conditions climatiques peuvent entraîner de profondes modifications dans la cinétique d'hivernage de l'espèce tandis que les opérations de régulation semblent ne pas avoir d'impact significatif sur la fréquentation de la population hivernante. Enfin, les conditions d'exploitation de certains ouvrages hydrauliques artificiels semblent favoriser sa présence à des périodes particulièrement sensibles.

\section{INTRODUCTION}

For thirty years, the great cormorant (Phalacrocorax carbo sinensis) population increase quickly in Europe. In France, the number of wintering birds increased from 4000 in 1970 to 100000 in January 2007 (Marion, 2007a). France has become the main European wintering area for this protected species.

The first European counting has given an estimation of 372300 breeding pairs, for a estimated population of 1200000 great cormorants throughout the whole Paleartic region (Van Eerden et al., 2008).

Simultaneously, a recent continental nesting expansion of the great cormorant was observed. Marion (1983) pointed out a nest on a colony of the Grand-lieu Lake (Loire-Atlantique department) and then in the Seine valley and the Somme valley. The first observation of great cormorant nesting in Eastern France was made by Remy (1986) at the Bischwald Lake in Lorraine (Moselle department). However, observation of great cormorant breeding was not made regularly in this area until 1997.

With the growing concern of the managers of aquatic ecosystems about the impact of this ichthyophagous bird on fishing communities, derogation measures for shooting were instituted in 1992 in the departments of the Ain, the Indre, the Loir et Cher and the Moselle. In 1996, Lebreton and Gerdeaux (1996) concluded that the prospect of stabilising the wintering populations in France would require an annual removal of 12\% (12000 birds, from the wintering population of 100 000). From 1997, the French Minister of Ecology allocated a yearly "quota" for the shooting of great cormorants shared between rivers, lakes and fish farms.

From 1998, shooting operations were authorised in all of departments of the North-east interregional delegation of ONEMA.

In this context, the North-east inter-regional delegation of ONEMA launched in 1997 a great cormorant population monitoring program in Alsace, Lorraine and Champagne-Ardenne regions. This program had different objectives:

- to monitor changes in the wintering population in these three regions;

- to monitor effects of shooting measures;

- to monitor the breeding population;

- to assess the impact of this piscivorous bird on aquatic systems.

The present paper is presenting monitoring program results.

The aim of this paper were to report on eleven years (1997-2008) of great cormorant monitoring in North-east of France (wintering and breeding population) and the first consequences of shooting actions reported on monitoring. We did not evaluate impacts of predation on fishes. Studies of bird stomach contents on the Marne river (Collas, 1998) and the Moselle river (Collas, 1999) and analyses of cormorant regurgitations at a roost site on the Der Lake (Collas et al., 2001) have been already made. 


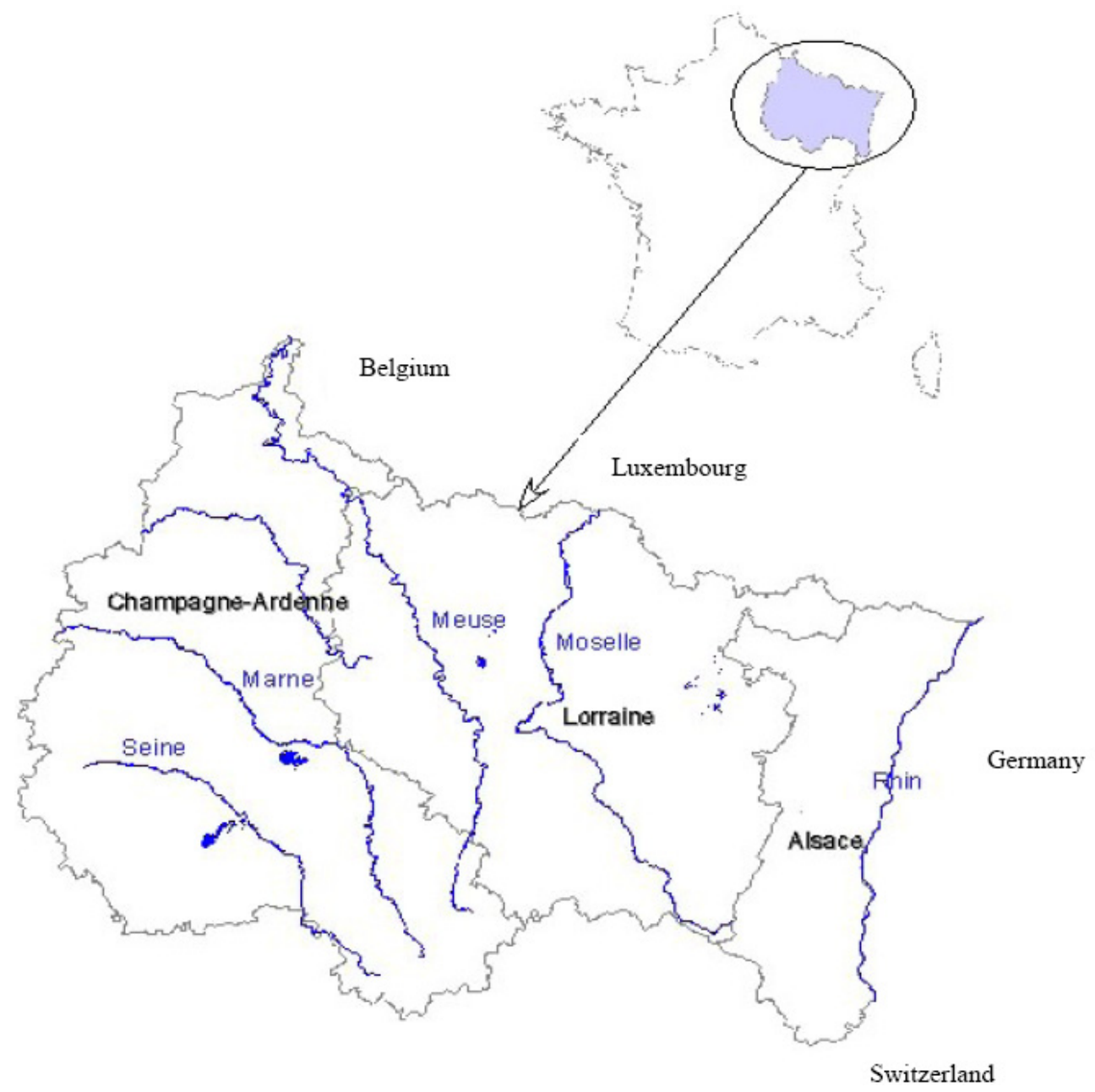

Figure 1

Location of the study area.

\section{MATERIALS AND METHODS}

\section{> STUDY AREA}

Study area $\left(57500 \mathrm{~km}^{2}\right)$ corresponds to Alsace, Lorraine and Champagne-Ardenne regions and covers five large river basins (Rhine, Meuse, Marne, Seine and Aube). Each region is composed of several administrative areas called departments. The site is at the heart of Europe on the frontier with Belgium, Luxemburg, Germany and Switzerland (Figure 1).

In Alsace region (the Rhine basin), studied area is the alluvial plain of Rhine river on the frontier between France and Germany, over a distance of approximately $180 \mathrm{~km}$. Rhine river is heavily modified (embanking, creation of the Alsacian Canal, creation hydroelectric dams). Also, the Rhine flood plain is occupied by large artificial lakes mainly created for gravel extraction. The biggest artificial lake, situated at Plobsheim (680 ha), regulate Rhine water upstream of Strasburg. The Rhine, along its Franco-German section, is also classified as an internationally important wetland under the RAMSAR convention since 2008.

Great cormorants observed in the Rhine valley frequent several roosting sites situated on German banks of the Rhine (Rhinau, Altenheim, Freistett, Ottenheim). These roosting sites have also been monitored and counted.

In Lorraine region, (the Moselle and Meuse basins), continental pisciculture is considered as the 3rd region in France for this activity (7000 ha of lakes, $1100 \mathrm{t} /$ year of production). This 
activity is particulary expanded on the departments of Moselle and Meuse. In this area, the Moselle alluvial plain is composed of many artificial lakes created for gravel extraction (2000 to 3000 ha) (Burgun, com. pers.).

In Champagne-Ardenne regions (the basins of the Marne and the Seine), four large artificial lakes were built to protect Paris from the flooding of Seine river and Marne river : the Der Lake (4800 ha) in 1974, the orient forest lake (2300 ha) in 1966, the Temple Lake (1840 ha) and the Amance Lake (480 ha) in 1990.

These lakes have very quickly become major sites in France and Europe for birdlife. Moreover, they are been designated under the RAMSAR Convention on Wetlands. Numerous species of migratory birds like the common crane (Grus grus) stop over during the migration. Thus, these lakes are the subject of special attention (hunting and wldlife reserves, national nature reserve) and human activities are subject to strict regulations.

\section{>COUNTING METHODOLOGY}

\section{Human means}

A network for the annual monitoring of the great cormorant population had to be set up for this study. Coordinated by ONEMA, censuses was conducted every month by ONEMA, the National Office for Hunting and Wildlife (ONCFS), the research Centre for Bird Population Biology (C.R.B.P.O.) (only for the Der lake), volunteers from ornithological societies (The League for the Protection of Birds) and from Federations or Associations for Fishing and Protection of Aquatic Ecosystems. Each counting exercise involved approximately one hundred observers.

\section{Wintering population}

Monitoring of wintering populations of great cormorants started in 1997 in Alsace, Lorraine and Champagne-Ardenne regions. Departmental committees for great cormorant monitoring were set up to harmonise the counting. The current methodology is based essentially on the national census protocol executed every two years and all results are included in different national syntheses in national censuses (Marion, 2003a).

The counting period runs from November to February, as near as possible to the fifteenth day of the month. The counting calendar is determined by ONEMA and communicated to all of the observers. The counting have been simultaneously on every sites.

The operation goal is to count birds when they arrive at their night roosting sites over the whole of the study area on the same day every month.

Observers have to be at the roosting site in the afternoon and count those already present without disturbing them. Then, they keep track of all those that arrive at the site for the night. In case of dispersion of the roosts, observers may be asked to visit others sites close by.

Information are recorded, summarised and transmitted after each count to the inter-regional delegation of ONEMA responsible for its processing. Shooting operations are suspended two days before each count in order to not disturb the roosts.

\section{The nesting population}

Monitoring of nesting sites was set up in 1997 for the study area. Nesting colonies are visited randomness once a month between March and June to count the number of nests, the number of young per nest and the number of young flying birds. Observations are made from afar in order to minimise disturbance of the sites. 


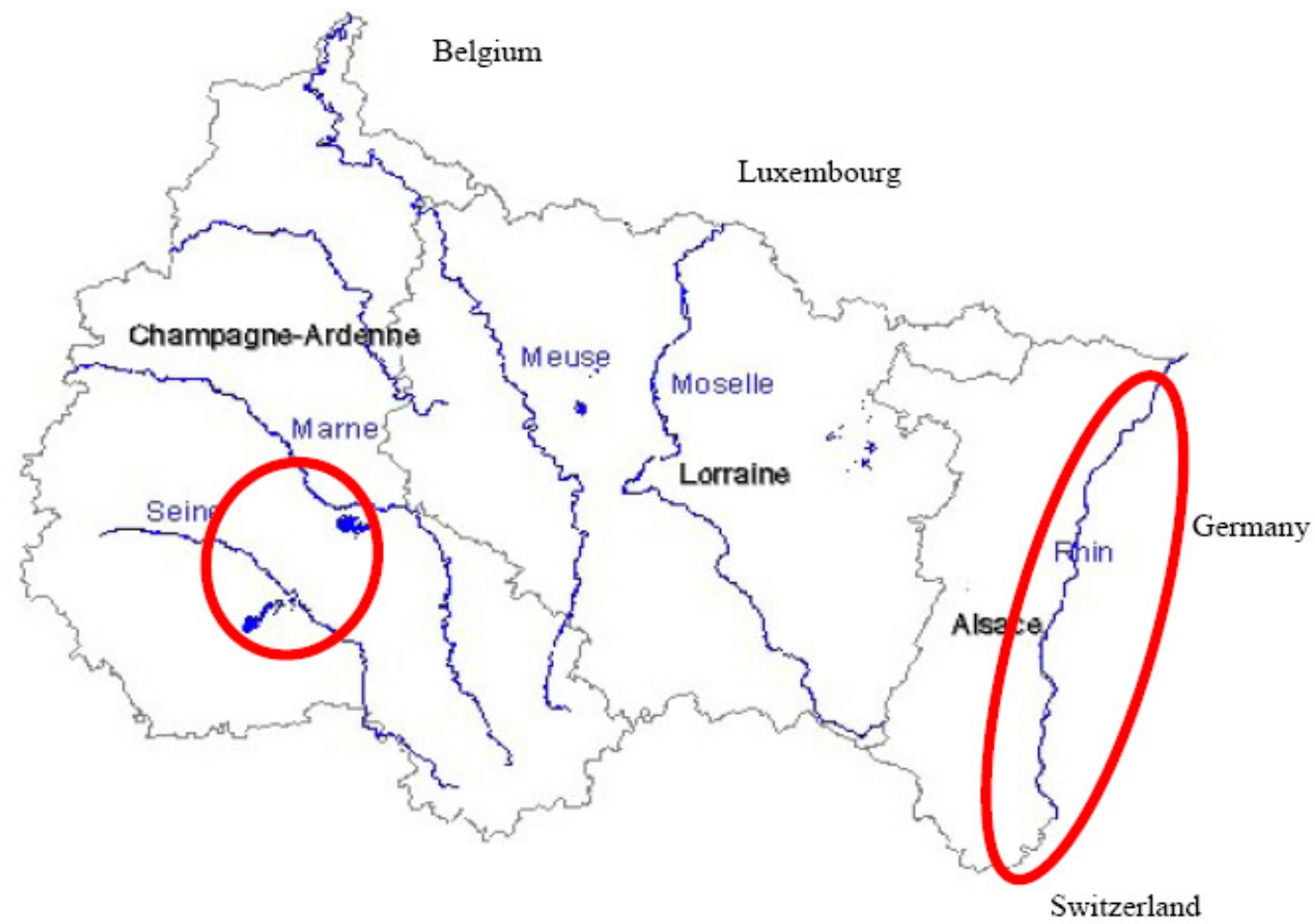

Figure 2

Location of areas concerned by protection status where cormorant shooting is forbidden.

\section{Shooting operations}

In 1997, the French Minister of Ecology allocated a yearly quota for the shooting of great cormorants. These quotas are given by department and authorizations are given to hunters to kill birds. Excepted two main areas concerned by protection status (Figure 2) (the Rhine valley and large artificial lakes in Champagne Ardenne (Brault et al., 2007)), culls are widespread in all regions. We don't know exactly on which sites shootings are conducted.

\section{RESULTS}

\section{> THE WINTERING POPULATION}

\section{Evolution at the inter-regional level}

The monthly counts made in the three regions between 1997 and 2008 are synthetised (Figure 2). The red curve corresponds to the January counts which are considered as representative of the wintering population. We can see that the overall frequentation increases steadily until 2004-05. The peak is reached in November 2004 with 18100 great cormorants counted (9300 for the Champagne-Ardenne region).

With the exception of the winters of 2002/2003, we also see that the peak of winter frequentation usually occurs in November during the postbreeding migrations (Figure 3). Then, numbers of birds recorded decrease gradually from December to February.

In spite of the great cormorant numbers seem to stabilize, an important increase of roost site number is observed (Figure 4). Indeed, numbers of occupied roost sites grew from around 50 to more than 100 during 11 years. However, we observed two decreases in 2003/04 (for November and December) and in 2006/07 for the four months.

Thus, 222 roost sites were already occupied at least once in 2007/08 (Figure 5) with a maximum of frequentation in 2007/08 with 128 sites occupied simultaneously. 


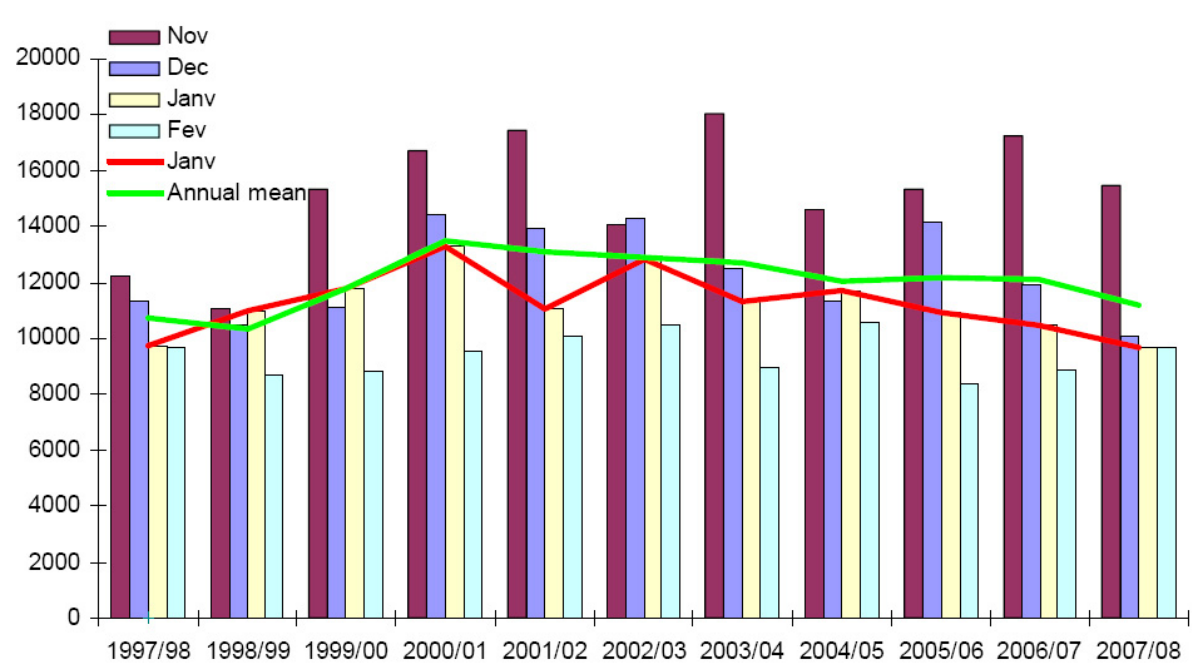

Figure 3

Development of the wintering population of the great cormorant in Alsace, Lorraine, ChampagneArdenne regions between 1997 and 2008.

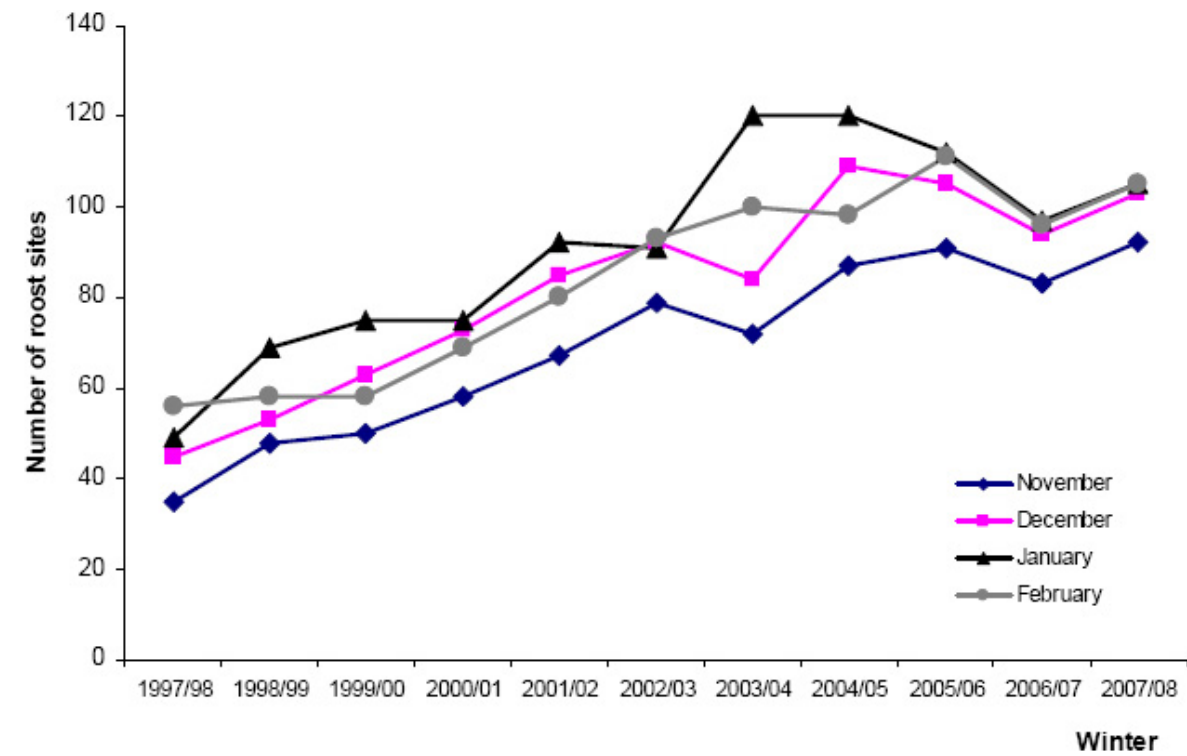

Figure 4

Development of roost sites between 1997 and 2008.

\section{Evolution at the regional level}

If we observe the repartition of birds by regional area, we see that Champagne Ardenne region represents the most important zone of wintering in November and December. Cormorant numbers is the lowest in Alsace region (Figure 6).

Observing countings of January, we see that numbers of birds recorded in Champagne Ardenne decrease steadily since 2000 , with two peaks in $2001 / 2002$ and $2007 / 2008$. In Alsace region, a small decrease is also observed since 2000 with a peak in 2001/2002 (Figure 6c). However, bird numbers seems to increase in Lorraine region in spite of important variability (Figure 6b).

If we observe monthly counts for these three regions, important differences could be noticed. Champagne Ardenne region shows the most important difference with a majority of birds in November and a heavy decrease in December. This phenomenon is not well marked in 


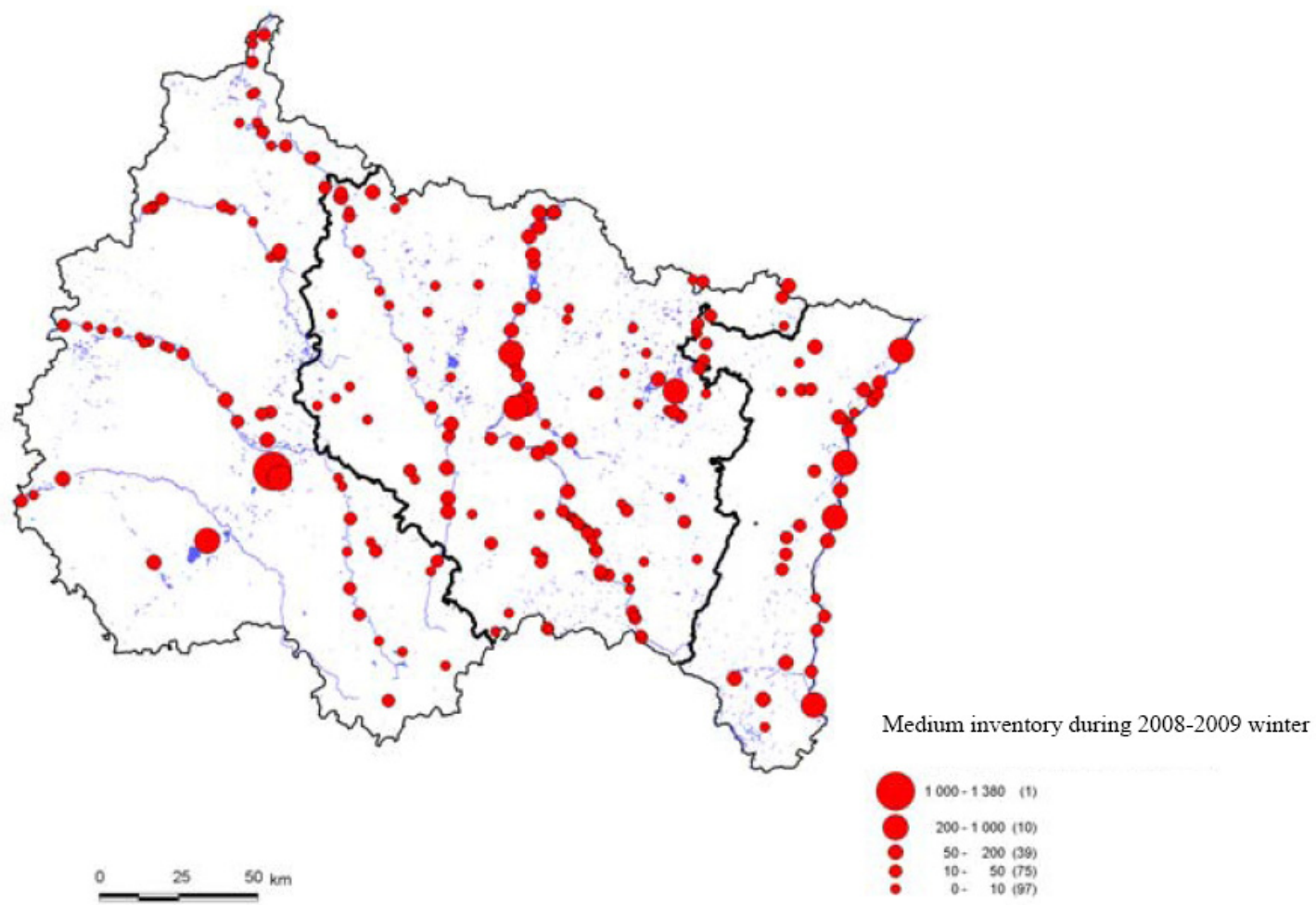

Figure 5

Locations of cormorant roosting sites in the Alsace, Lorraine and Champagne-Ardenne regions.

Alsace and Lorraine with peaks localized mainly in January (5/11 years in Lorraine, $7 / 11$ years in Alsace).

\section{Evolution at the site level: the Der Lake}

The Der Lake is the biggest roost site observed in the Nord-East of France. If we observe wintering cormorant number, we see that evolution is representative of interregional trend (Figure 7).

In November 2003, number of birds felt down to 1950 (reduction of $75 \%$ compared to the previous year). This fall occurred with the ten-yearly draining of the reservoir when water level is lower than usual to inspect dam structure. To preserve stocks, fishermen have resorted scaring measures to prevent bird predation during this critical period with a permanent human presence on the reservoir to disturb the predator from the usual feeding grounds. We don't know exactly which action was determinant (scaring measures or drainage itself) but, in parallel, frequentation on the neighbouring lakes of the Orient Forest Lake increased from 2350 birds in November 2002 to more than 4600 in November 2003 (+95\%).

\section{> THE NESTING POPULATION}

The first observation of great cormorant nesting in Eastern France was made at the Bischwald Lake (300 ha) in Lorraine (Remy, 1986). But it wasn't until 1997 that the great cormorant started to nest regularly in the region: the first reproductive colonies were established in the 3rd region in France for continental fish farming (Collas, 1997).

The evolution of the number of apparently occupied nests (AON) observed during the 19972008 period in the three regions is significant (Figure 8). 


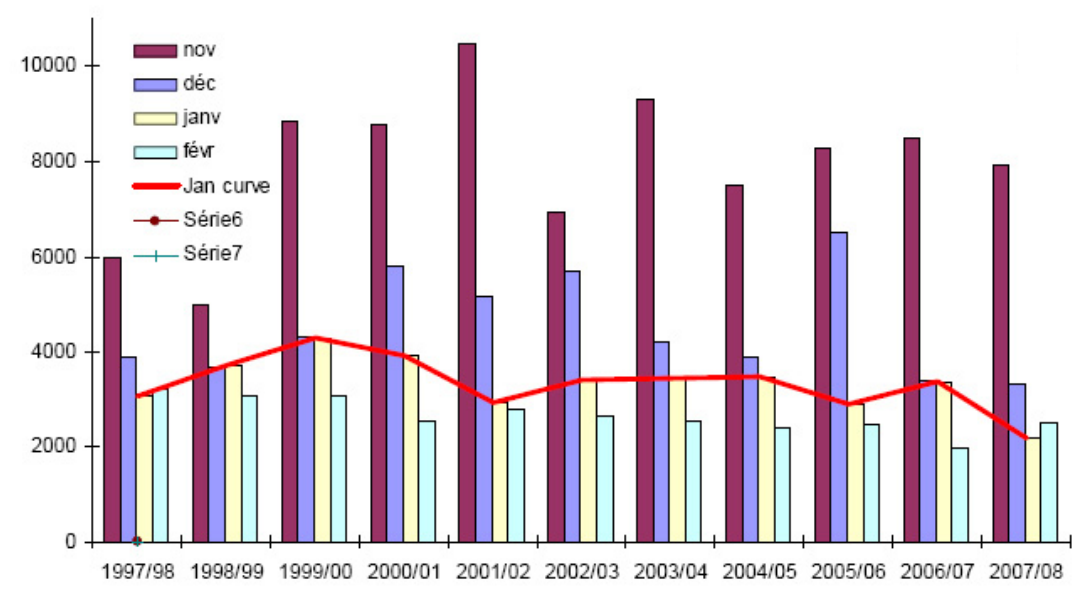

(a)

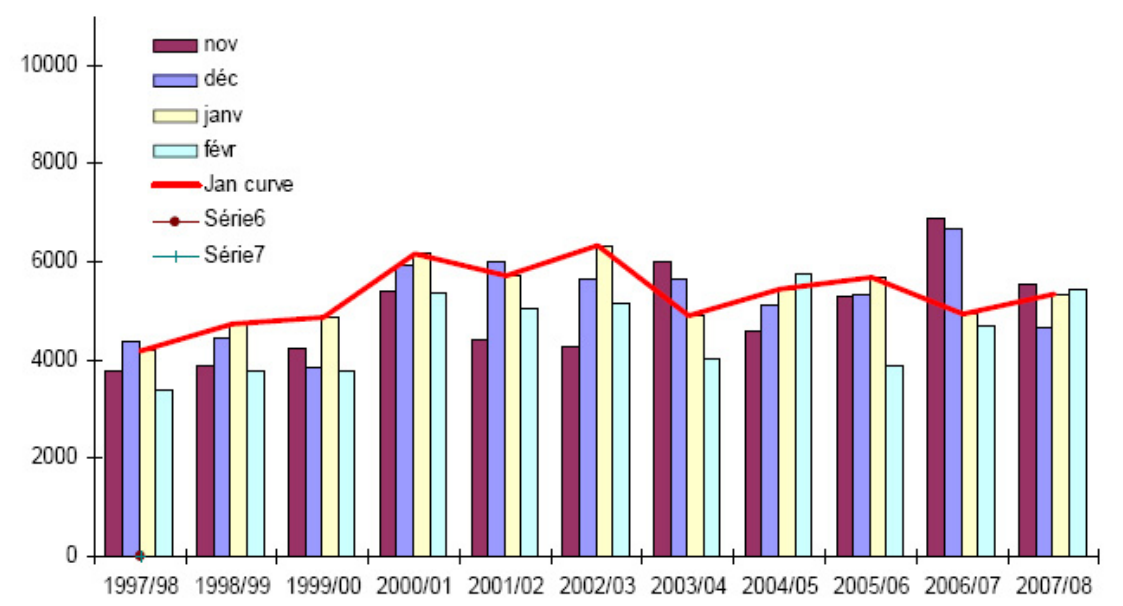

(b)

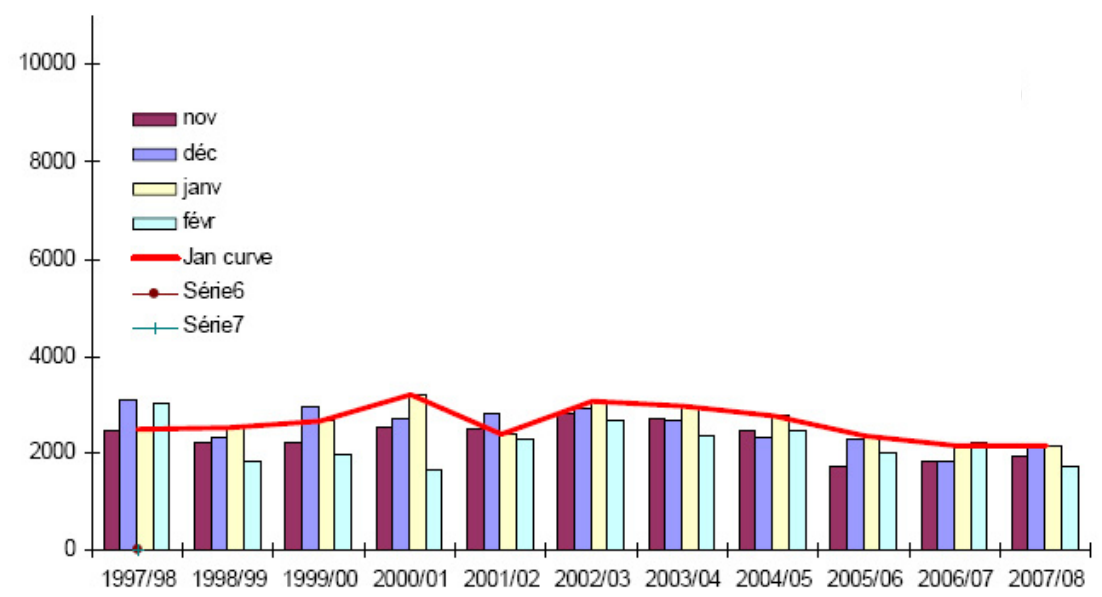

(c) 
M. Collas and V. Burgun: Knowl. Managt. Aquatic Ecosyst. (2011) 403, 05

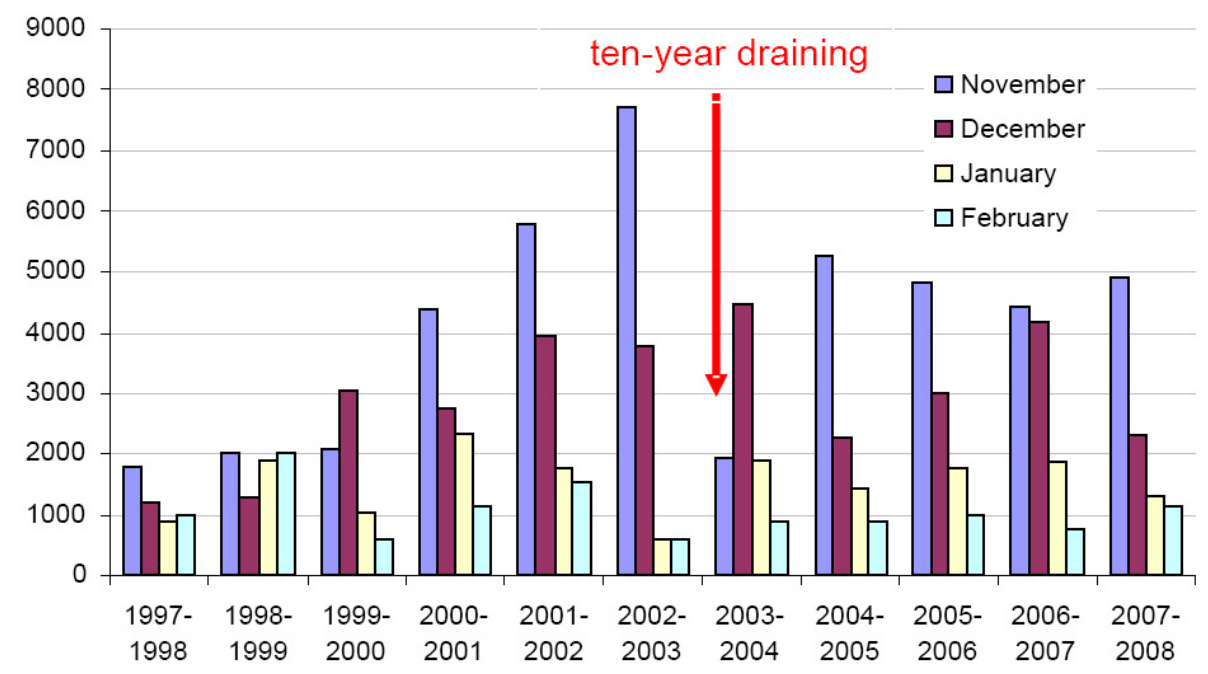

Figure 7

Numbers of wintering cormorants in particular months on the Der Lake in 1997-2008.

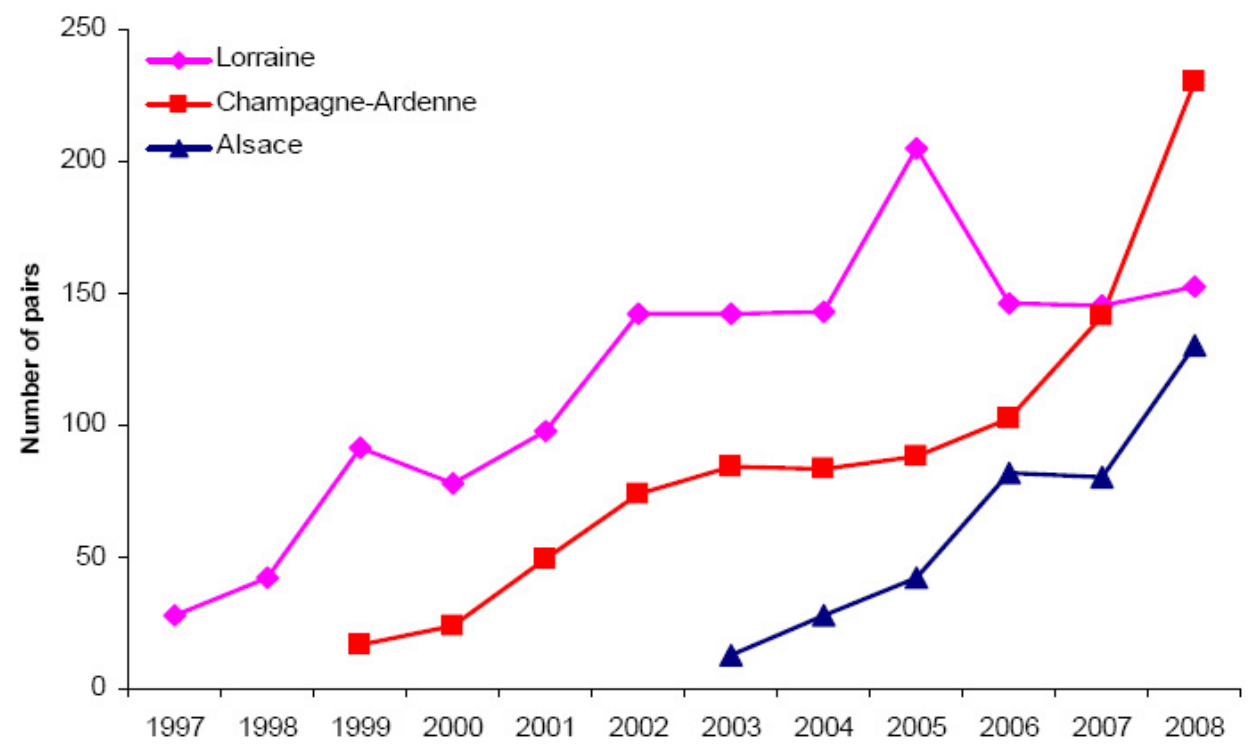

Figure 8

Evolution of the number of apparently occupied nests - Alsace, Lorraine, Champagne-Ardenne, 19972008.

We see that the great cormorant has been nesting in the three regions since 2003 (Collas, 2005). The number of AON has increased steadily at an average annual growth rate for the three regions of $30.2 \%$.

\section{The situation in Lorraine region}

From 1997, two pioneer sites (Vallerange, Rodalbe) appeared in the Moselle department on lakes where extensive fish farming is conducted, providing plentiful and easily obtainable food. A total of 28 AON were counted in these two colonies (Collas, 1997).

The nesting population increased in this area and continued on different pisciculture lakes (Rhodes, Bischwald lake, Lindre Lake). After a stabilisation at around 140 AON between 2002 and 2004, the number of reproducing AON increased to reach 205 in 2005 in 4 colonies. 


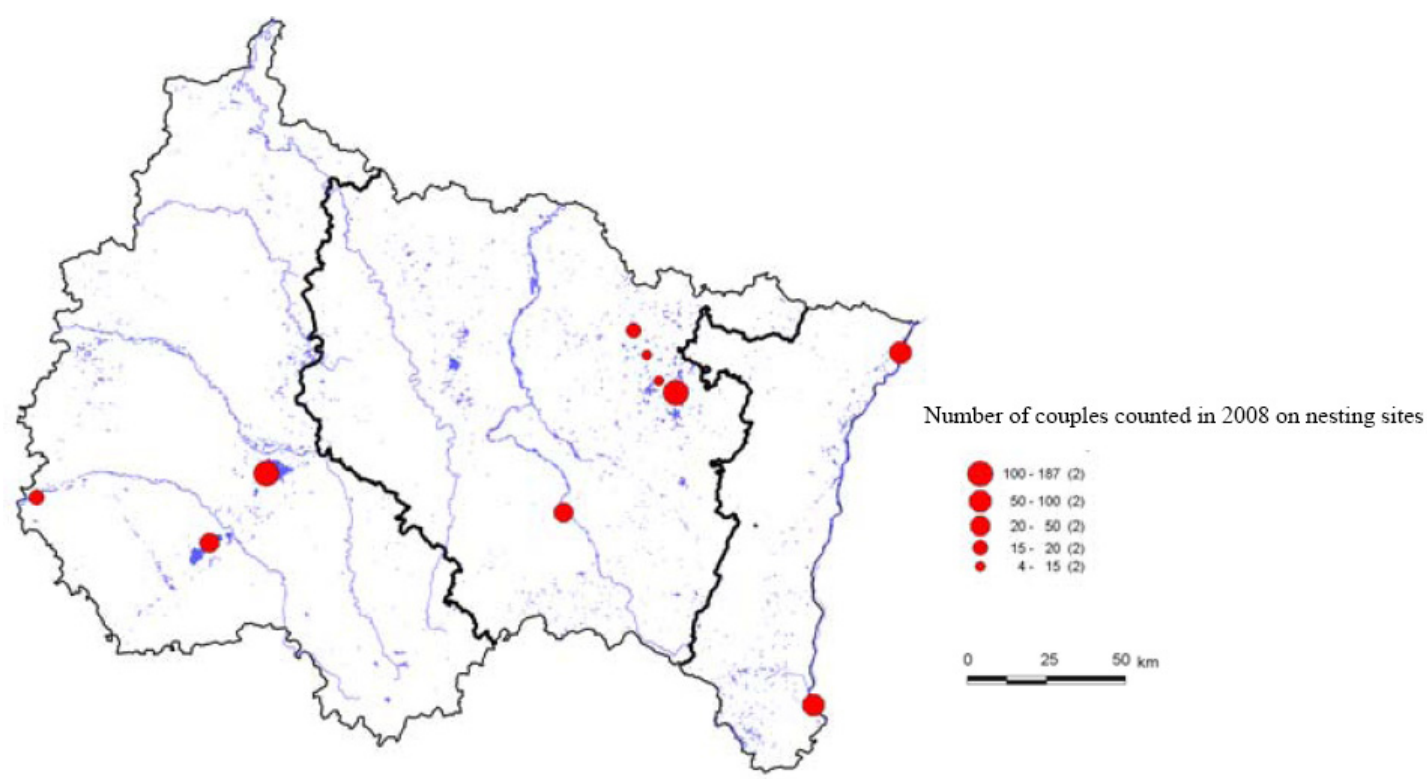

Figure 9

Location of the nesting sites in the study area in 2008.

Then, we observe a considerable decrease between 2006 and 2008. This situation can be linked with the disturbances directed at the colonies around piscultures by gas guns.

In the Lorraine region, nesting is observed in two departments (Moselle and Vosges in 2006) and 7 sites have been used by the great cormorant, at a peak figure of 205 couples. In 2008 , we counted 5 reproductive colonies of 152 couples (Figure 9) with the number of young estimated at 2.8 per nest. The average annual growth rate of the number of reproductive couples in Lorraine is $16.6 \%$. This is the region in which the increase is the slowest. Apart from the Sainte-Croix colony, which is relatively undisturbed (leisure activity animal park), all the other colonies in Lorraine are subject to disturbance from human activities (fish farming) and the culling of reproductive birds.

\section{The situation in Champagne-Ardenne region}

The great cormorant nested for the first time in 1999 in the Champagne-Ardenne region, in the Marne department, at the Der Lake (16 couples). This colony grew steadily to reach 187 couples en 2008 and become the largest nesting site in Nord-East of France.

Several small colonies were observed along the Marne river and the Meuse river, in the Ardennes department (Collas, 2005) and along the Seine river in Aube department.

In 2007, nesting was also recorded on the orient forest lake (the Seine basin), on a promising site, rather like the Der Lake.

In 2008, three colonies were observed in Champagne-Ardenne region with a total of 230 couples. At the Der Lake, the average annual growth rate in the number of couples rises to $33.6 \%$ and we must assume that the main colonies are far from having reached their saturation point. Birds find all the calm they need because of the legal status.

\section{The situation in Alsace region}

Nests of the great cormorant were first seen in Alsace region in 2003 at the roosting site of Beinheim in the Bas-Rhin department where 55 couples have now been counted. A new colony of 13 couples was identified in 2005 at the roost site of Kembs in the Haut-Rhin 


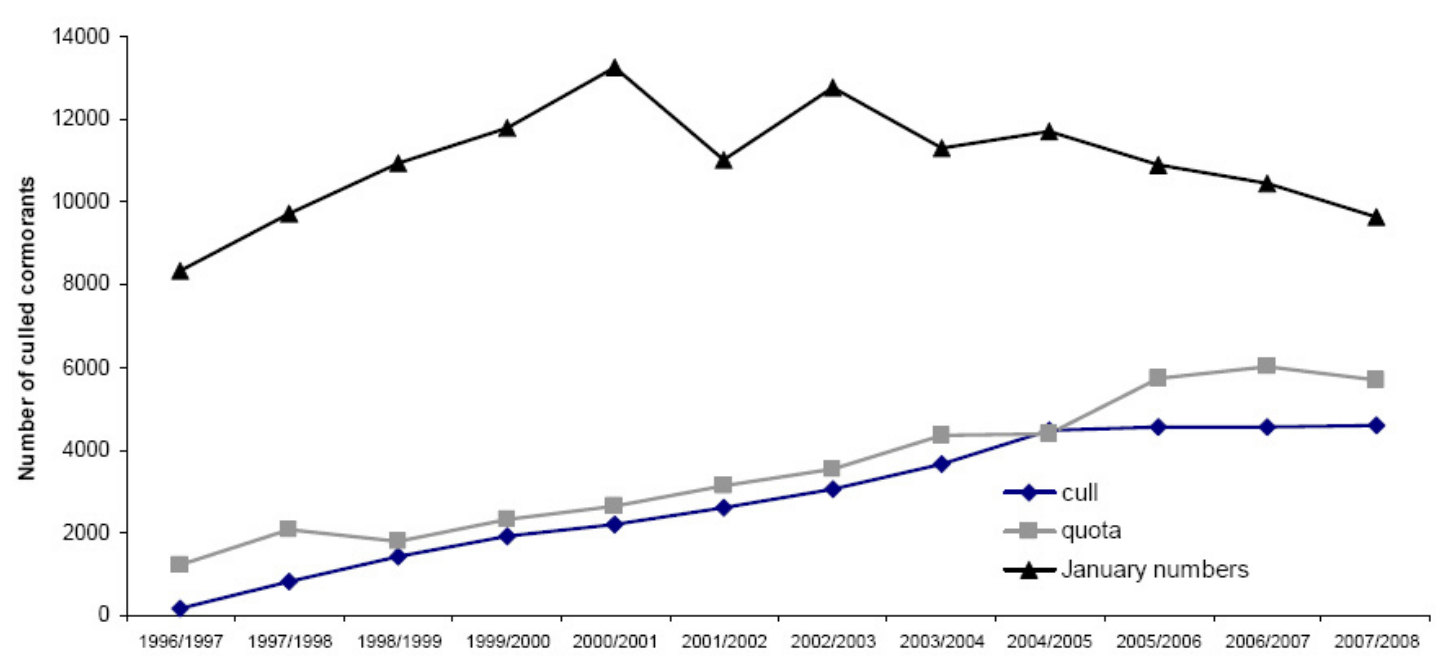

\section{Figure 10}

Evolution of great cormorant shot in Alsace, Lorraine, Champagne-Ardenne region in accordance with authorised quotas and recorded populations - Winters 1996/1997 to 2007/2008.

department. This colony doubled its numbers in 2005 and again in 2006 to reach 75 couples in 2008.

In total, two colonies consisting of 130 pairs were recorded in Alsace region in 2008. It is in this region that the average annual growth rate in the number of pairs is the highest $(+58.5 \%)$.

\section{> REPORT ON SHOOTING OPERATIONS OF THE GREAT CORMORANT}

\section{Inter-regional situation}

Evolution of cormorant shot (quotas, individuals culled, numbers recorded) have been recorded during the 1997-2008 period in the 3 regions of North-East of France (Figure 10). Regional quotas had increased significantly in the three regions, rising from 1218 birds in 1998 to 5680 birds for the winter of 2007/2008. In parallel, the number of birds culled rose from 180 in 1996/1997 to 4605 during the winter of 2007/2008. The cull represents $47.6 \%$ of the recorded number of birds in mid-January 2008.

\section{Table I}

Percentage of birds culled compared to recorded population.

\begin{tabular}{|l|c|c|c|c|c|}
\hline Winter & $2003 / 2004$ & $2004 / 2005$ & $2005 / 2006$ & $2006 / 2007$ & $2007 / 2008$ \\
\hline $\begin{array}{l}\% \text { of birds culled/ } \\
\text { recorded population }\end{array}$ & $32.3 \%$ & $38.3 \%$ & $41.8 \%$ & $43.7 \%$ & $47.6 \%$ \\
\hline
\end{tabular}

The culls intensified from 2003/04 onwards, as the table below shows, in 5 years representing up to $47.6 \%$ of the recorded inter-regional population.

\section{Regional situations}

The culling operations are the most important in Lorraine region: during the winter of 2007/08, they represented $61 \%$ of the inter-regional culls. In the four departments of Lorraine region, the numbers progressed until January 2003 when shooting operations increased quickly to a 
steady rate of between 2800 and 2900 birds culled in the last four winters. The birds removed during the 2007/08 winter represent $53 \%$ of the regional population recorded in January 2008. Shootings take place essentially in the piscicultures of the Moselle department and the whole of the Moselle valley.

In Champagne-Ardenne region, the number of birds culled has continued to increase but seems to be stable for the last two winters. However, the wintering population decreases since $1999 / 2000$. During the winter of $2007 / 08$, the cull represented $67 \%$ of the wintering population counted in January.

Shooting operations is lowest in Alsace because shooting is prohibited in the Rhine valley making it difficult to fulfil the quotas. Culls represent $15 \%$ of the regional wintering population counted in January 2008.

At inter-regional level, culls are not statistically correlated with number of wintering birds. We think that the culls do not have a great impact on the wintering numbers, according to Marion (2005). The hypothesis of substitution of shot birds by new arrivals should be possible.

\section{CONCLUSION-DISCUSSION}

The monitoring of the great cormorant that started in 1997 in the Alsace, Lorraine and Champagne-Ardenne regions has revealed two trends. The first relates to the wintering population: the number of great cormorant grew steadily until January 2001 (average annual increase of $+16 \%$ ) but since 2002 a gradual decrease in numbers has taken place at an average annual rate of $-4.5 \%$ and there are less than 10,000 birds in January 2008 .

This increase of cormorant numbers is associated with an important development of new wintering sites and an increase in frequentation of well known sites.

\section{> MOVEMENTS DURING THE WINTER}

The monitoring of wintering population can help to describe wintering movements of the great cormorant in these three regions. Three distinct phases can be characterized:

- The arrival of the migratory flows: the peak of visits is always during November and corresponds to the postbreeding migration. So, this period sees a large number of birds gathering in the zones of settlement or migratory transition at the large reservoirs of ChampagneArdenne region (Der Lake and the orient forest lake). The greatest number is recorded at these man-made lakes where the birds are not only left in peace (no regulation), but also enjoy easy access to food. The hydraulic management of these structures involves considerable lowering of the water levels and facilitating the feeding of birds.

In areas where pisciculture activities are important, birds arrive earlier during periods of draining and fishing (Collas, 2005).

- The establishment of winter sites: This phase takes place between December and January and the population steadily decreases. A decrease in recorded population in December is probably due to migrations to warmer areas in the southern Europe (Bregnballe et al., 1997). It is generally confirmed in January when the population is well-established in wintering sites. The January period is reckoned to be the best for counting the wintering population and monitoring its development. French national counting is conducted at this time because counting is representative of wintering population.

Over these two months, we also see a reduction of the inter-regional population, a modification in the bird distribution which are mostly counted at the roosting sites established on the river network. Predation takes place essentially on open waters and associated areas (gravel pits in the flood plain). But this may also be restricted to the rivers and streams as, during the winters of 2001/02 and 2002/03, following the icing of a large number of borrow pits, $84 \%$ and $94 \%$, respectively, were seen on the rivers (Collas, 2005). 
- Departure to breeding areas: prebreeding migrations start in February, corresponding to the departure of birds to breeding colonies in the north of Europe. Moreover, we saw that the first reproducing birds also appear at the nesting zones situated on the Moselle piscicultures.

\section{> THE EFFECTS OF SHOOTING}

The wintering population of in these regions is subject to large scale shooting operations. In winter 2008-2009, 4600 birds were culled. It is therefore tempting to see a link between this level of culling and the decrease observed since 2002. We can compare this situation to that of a neighbouring country like Belgium where shooting only developed after 2007.

In fact, in the two countries there is a great similarity in the development of the population since the wintering population in Belgium shows a regular decrease of winter numbers from 2003. Paquet (2008) indicates a stabilisation in numbers during the $2007 / 08$ wintering, after a period of marked decrease between 2003 and 2007 . Therefore, we can clearly see that, across these two territories whether shooting is conducted or not, the wintering population has developed in an identical fashion. We can conclude that observed decrease is not linked with shooting in accordance with Marion (2003) and Paquet (2005). Frederiksen et al. (2001) also conclude that culls probably have had a limited effect on cormorant populations, but if carried out in a density-dependent way they could stabilize numbers near a desired level. Moreover, we can emphasise that regulation by shooting only very partially influences the local numbers, the birds shot in this attractive zone being rapidly replaced by a constant flow of new wintering and migrating birds (Keller and Lanz, 2003). However, at the European level, the hypothesis of an impact of European culls on the whole population should be possible.

\section{>IMPACT OF TEMPERATURE ON CORMORANT NUMBERS}

Frederiksen et al. (2002) have shown that a bird returns to the same wintering site but that several other parameters may influence the wintering of the great cormorant in these three regions, modifying the degree of frequentation and distribution over the various ecosystems. Climatic conditions seem to have impacts on the wintering population and can affect the migration periods and the time of residence at the roost sites. Critical climatic events can modify the diet behaviour of the great cormorant: when gravel pits are totally frozen, birds need to search food elsewhere.

These episodes provoke different types of response from the wintering population directly associated with the intensity of the climatic conditions. Cold spells are usually followed by an early departure of the birds to areas where food is available. So, we assume an appreciable decrease of recorded birds at regional level because counted roost sites are mainly at still water areas. This situation was observed in January 2002 with a fall in numbers in all the regions being monitored and during the winter 2008-2009 (Collas, 2009).

During very cold periods, we see large scale movements of birds to the headwater. The icing of still water (large artificial reservoirs, fisheries and gravel pits) results in transfers to rivers and streams. We also see an increase in numbers at the counted roosting sites on open waters and the appearance of "new" roosting sites where no bird was recorded before. This type of event is particularly well observed on the Moselle basin where the birds leave the large roosting sites situated in an area of high concentration of gravel pits, for the neighbouring basin of the Meuse and roosting sites of the high basin of the Moselle.

An other consequence of a cold spell may overcrowd the study area. During the winter of 2002/03 the number of counted birds increased steeply in January, following a cold spell that affected the whole of Europe. Probably, birds from surrounding areas attempted to escape conditions that were even less favourable (Marion, 2003b).

If we look at the temperature data, we can suppose a link between temperature and the size of the wintering population. We see that winters 1999/2000 and 2000/01 were particularly 
mild with no negative temperature. In 2000/01, the warmest winter of the ten year period corresponds to the peak of frequentation in the three regions (13276 great cormorants). During the following winter 2001/02, negative temperatures have seemed to decrease the number of birds.

\section{> THE HYDRAULIC MANAGEMENT OF MAN-MADE STRUCTURES}

Biggest changes in development of population have taken place in Champagne Ardennes region while shooting is prohibited at the main roosting sites (the Der Lake and the orient forest lake).

The Aube basin and the Marne basin are situated on the main migratory route of Western Europe and, since the creation of reservoir lakes have become essential stopover points for numerous migratory species (Dubois et al., 1991).

The attraction of these lakes is increased by the particular management of these structures. The hydraulic cycle is reversed compared to the functioning of natural wetlands (high waters in winter and low at the end of the summer). The filling of the reservoirs starts the 1st November and ends at the end of June. The emptying starts immediately in July to finish at the end of October. This operation implicate a considerable annual variation of tidal range (12 $\mathrm{m}$ for the Der lake, $16 \mathrm{~m}$ for the Temple lake) that can be greater when the ten-year draining takes place for structural inspections.

So, the structures are at their lowest level when the migrations are in full swing and it is at this period that peaks in numbers are recorded (November).

Immense mudflats appear with the large variations of the water level. These habitats are particularly attractive for wading birds and crate numerous small islands much liked by wetland birds like the great cormorant (resting places, roosting sites).

During the whole draining period that may be prolonged if there is a lack of rainfall, fishes are concentrated in reduced areas of water, and this is where the cormorant can do most of its fishing. These sites are therefore very welcoming to the great cormorant, being undisturbed and offering easily obtainable food.

\section{> DEVELOPMENT IN THE NESTING POPULATION}

The last national census of nesting great cormorants in 2006, identified 4094 nesting pairs for the continental population (2807 in 2003) distributed over $46 / 47$ colonies. It corresponds to an average annual growth rate of $14.9 \%$ (Marion, 2004, 2007b).

In the Nord-East of France, the great cormorant has been nesting in the three regions since 2003 and 10 colonies have been recorded with a total of 512 pairs. The average annual rate of increase is much higher than the national average (14.9\%) reaching $30.2 \%$, with variable regional situations depending on wintering behaviour and shooting. This increasing trend is also observed in other countries like in Baltic countries (Herrmann et al., 2009) or in Belgium (Jenard, 2005). Situation seems to be different in Luxembourg where no nesting pairs have been already observed (Proess et al., 2009).

The example of the Moselle department shows that shooting can have an immediate effect on the populations and the local colonies. In this department, culls are authorised until 30th March to protect the piscicultures. Now in this period, the reproducing birds are already present in the colonies and the culls carried out at this time of the year, close to nesting sites, means that reproducing birds are removed contrary to the effect of the winter culls when it is young birds that are in the majority. This approach means that the development of the nesting population has been slowed in Lorraine and, from 2006, the number of couples fell from 205 to 146 in the following year. This type of operation has the disadvantage that it disturbs all of the bird life a great deal during a sensitive period (nesting). 


\section{ACKNOWLEDGEMENTS}

We would like to express our gratitude to all the observers: agents of ONEMA, ONCFS, volunteers from nature protection associations, members of the Certified Associations for Fishing and the Protection of Aquatic Ecosystems, etc. without whom this study would not have been possible.

\section{REFERENCES}

Brault H., Schwoerer M.L. and Lefranc J.M., 2007. Fleuves, Lacs, Etangs : Une gestion adaptée des réserves du Nord-Est. Faune Sauvage, 287, 26-30.

Bregnballe T., Frederiksen M. and Gregersen J., 1997. Seasonal distribution and timing of migration of Cormorants Phalacrocorax carbo sinensis breeding in Denmark. Bird Study, 44, 257-276.

Collas M., 1997. Nidification du Grand Cormoran (Phalacrocorax carbo) dans le département de la Moselle, DR $n^{\circ} 3$ du Conseil Supérieur de la Pêche, Délégation Régionale de Metz, Document ronéotypé, $13 \mathrm{p}$.

Collas M., 1998. Approche du régime alimentaire du Grand Cormoran (Phalacrocorax carbo) rivières : Marne, Saulx et Moselle, hiver 1997/1998, Conseil Supérieur de la Pêche, Délégation Régionale de Metz, document ronéotypé, $23 \mathrm{p}$.

Collas M., 1999. Comportement alimentaire du grand cormoran sur la rivière Moselle, Conseil Supérieur de la Pêche, Délégation Régionale de Metz, document ronéotypé, $37 \mathrm{p}$.

Collas M., 2005. Le grand cormoran en Alsace, Lorraine, Champagne-Ardenne - Résultats des recensements hiver 2004/2005 - Évolution de la population de 1997 à 2005, Conseil Supérieur de la Pêche, document ronéotypé, 27 p. et annexes.

Collas M., 2009. Grands cormorans, recensements du 14 janvier 2009, Alsace, Lorraine et ChampagneArdenne, Compte-rendu de comptage $n^{\circ} 43,4 p$.

Collas M., Guidou F. and Varnier R., 2001. Étude du comportement et du régime alimentaire du Grand cormoran Phalacrocorax carbo sur le lac du Der (Marne et Haute-Marne). Alauda, 69, 513-526.

Dubois J.M., Fauvel B., Pierre D., Riols C., Rouable D. and Sauvage A. 1991. Les oiseaux de la Champagne-Ardenne, Centre Ornithologique de Champagne-Ardenne. In: Némont S.A. (ed.), Barsur-Aube, $290 \mathrm{p}$.

Frederiksen M., Lebreton J.D. and Bregnballe T., 2001. The interplay between culling and densitydependence in the great cormorant: a modelling approach. J. Appl. Ecol., 38, 617-627.

Frederiksen M., Bregnballe T., Van Eerden M.R., Van Rijn S. and Lebreton J.-D. 2002. Site fidelity of wintering cormorants Phalacrocorax carbo sinensis in Europe. Wildl. Biol., 8, 241-250.

Herrmann C., Bregnballe T., Larsson K., Ojaste I. and Lilleleht V., 2009. Population Development of Baltic Bird Species: Great Cormorant (Phalacrocorax carbo sinensis), HELCOM Indicator Fact Sheets 2009. Online.

Jenard P., 2005. Evolution of the breeding population of the Great Cormorant (Phalacrocorax carbo) in the western part of Wallonia (Belgium, Hainaut Province) between 1992 and 2005. Aves, 42, 313-324.

Keller T.M. and Lanz U., 2003. Great Cormorant Phalacrocorax carbo sinensis management in Bavaria, southern Germany - What can we learn from seven winters with intensive shooting? Vogelwelt, 124, Suppl., 339-348.

Lebreton J.D. and Gerdeaux D., 1996. Gestion des populations de grand cormoran (Phalacrocorax carbo) séjournant en France, Ministère de l'Environnement, $43 \mathrm{p}$.

Marion L., 1983. Problèmes biogéographiques, écologiques et taxonomiques posés par le grand cormoran Phalacrocorax carbo. Revue Écologique (Terre Vie), 38, 65-99.

Marion L., 2003a. Recensement national des grands cormorans hivernant en France durant l'hiver 2002/2003 - Rapport final - Bilan corrigé au 12 décembre 2003, Ministère de l'Écologie, du Développement et de l'Aménagement Durables, Direction de la Nature et des Paysages, Laboratoire d'Évolution des Systèmes Naturels et Modifiés, UMR 6553, Ecobio, Muséum National d'Histoire Naturelle and Université de Rennes, 35 p. 
Marion L., 2003b. Recent development of the breeding and wintering population of Great Cormorants Phalacrocorax carbo in France - Preliminary results of the management plan of the species. Vogelwelt, 124, 35-39.

Marion L., 2004. Recensement National des Grands Cormorans nicheurs en France en 2003. Ministère Écologie et Développement Durable, Université de Rennes 1, CNRS, SESLG, 17 p.

Marion L., 2005. Recensement national des grands cormorans hivernant en France durant l'hiver 20042005 - Rapport final - Bilan corrigé au 6 décembre 2005 - Ministère de l'Aménagement du Territoire et de l'Environnement, Direction de la Nature et des Paysages, Laboratoire d'Évolution des Systèmes Naturels et Modifiés, UMR Ecobio, Muséum National d'Histoire Naturelle et Université de Rennes 1, 32 p.

Marion L., 2007a. Recensement national des grands cormorans hivernant en France durant l'hiver 2006/2007 - Rapport final - Bilan corrigé au 30 novembre 2007, Ministère de l'Écologie, du Développement et de l'Aménagement Durables, Direction de la Nature et des Paysages, Laboratoire d'Évolution des Systèmes Naturels et Modifiés, UMR Ecobio, Muséum National d'Histoire Naturelle et Université de Rennes, 37 p.

Marion L., 2007b. Recensement National des Grands Cormorans nicheurs en France en 2006. Rapport final, Ministère Écologie, du Développement et de l'Aménagement Durables, Direction de la Nature et des Paysages - SESLG Université de Rennes 1, 22 p.

Paquet J.Y., 2005. L'hivernage du Grand Cormoran (Phalacrocorax carbo) se stabilise-t-il en Wallonie et à Bruxelles ? Résultats des recensements coordonnés des dortoirs en Wallonie et à Bruxelles, saison 2004-05.

Paquet J.Y., 2008. Les recensements coordonnés des dortoirs de grands cormorans (Phalacrocorax carbo) en Wallonie et à Bruxelles : hiver 2007/2008. Aves, 45, 183-185.

Proess R., Keller T. and Lorge P., 2009. Der Kormoran Phalacrocorax carbo sinensis in Luxemburg - Zusammenfassung der Winterzählungen und Nahrungsanalyse durch Speiballenuntersuchung. Regulus Wissenschaftliche Berichte No. 24, 21 p.

Remy J.M., 1986. Première nidification du grand cormoran (Phalacrocorax carbo) en Lorraine. Ciconia, 20, 61-67.

Van Eerden M., Marion L., Parz-Gollner R., Bregnballe T., Van Rijn S. and Volponi S., 2008. Cormorants in the Western Palearctic: distribution and numbers on a wider European scale, IUCN/Wetlands International Cormorant Research Group, Rijkswaterstaat, NL, 4 p. 